Situs Jurnal : http://ejournal.stiepancasetia.ac.id/index.php/jieb

Jilid 6 Nomor 1 Maret 2020

Hal 54 - 59

\title{
ANALISIS KINERJA LAPORAN KEUANGAN PADA KOPERASI TANI CATUR KARYA DESA SARI MULYA KECAMATAN SUNGAI LOBAN KABUPATEN TANAH BUMBU PERIODE 2012-2017
}

\author{
Maria Anastasia, SE. MM, Nicco Dadang Ardeansyah
}

Sekolah Tinggi Ilmu Ekonomi Pancasetia, Jl. Ahmad Yani. Telp. (0511) 3256560

Fax. (0511) 3256557 Banjarmasin - 70248 e-mail : niccodadang@ gmail.com

Abstrak :

Tujuan dari penelitian ini adalah untuk mengetahui dan menganalisis Laporan keuangan pada Koperasi Tani Catur Karya Kecamatan Sungai Loban Kabupaten Tanah Bumbu.

Metode yang digunakan dalam penelitian ini adalah metode kuantitatif dengan pendekatan kualitatif dan teknik analisis data menggunakan 6 Aspek yaitu Aspek Permodalan, Aspek Kualitas Aktiva Produktif, Aspek Efisiensi, Aspek Likuiditas, Aspek Kemandirian dan Pertumbuhan, dan Aspek Jati Diri Koperasi untuk mengetahui tingkat kesehatan laporan keuangan Koperasi Tani Catur Karya Desa Sari Mulya Kecamatan Sungai Loban Kabupaten Tanah Bumbu.

Kata Kunci : Analisis Kinerja Laporan Keuangan.

\section{Latar Belakang}

Koperasi mempunyai arti bekerja sama. Adanya kerja sama dimaksudkan untuk mencapai tujuan yang semula sukar di capai oleh orang perorangan, tetapi akan mudah dicapai bila dilakukan dengan kerja sama antara sebagian atau sekelompok orang. Oleh karena itu koperasi sangat perperan penting dalam mewujudkan pembangunan dalam mensejahterakan perekonomi rakyat. Tujuan koperasi adalah untuk memajukan kesejahteraan anggota pada khususnya dan masyarakat pada umumnya serta ikut membangun tatanan perekonomian nasional dalam rangka mewujudkan masyarakat yang maju, adil dan makmur yang berlandaskan Pancasila dan Undang-undang Dasar 1945. Penilaian prestasi atau kinerja suatu perusahaan diukur karena dapat dipakai sebagai dasar pengambilan keputusan baik pihak internal maupun eksternal.
Sama halnya dengan perusahaanperusahaan pada umumnya, koperasi juga merupakan suatu alat yang dapat digunakan untuk mengetahui kinerja keuangan pada koperasi agar manajemen dari pihak koperasi dan dapat melaksanakan tugas serta kewajibannya dengan baik sesuai dengan tujuan koperasi pada umumnya. Koperasi merupakan salah satu bentuk organisasi ekonomi yang sedang mendapatkan perhatian oleh pemerintah. Koperasi merupakan suatu organisasi yang berbadan hukum. Pembangunan koperasi di Indonesia merupakan bagaian dari usaha pembangunan nasional secara keseluruhan. Koperasi harus dibangun untuk menciptakan usaha dan pelayanan dalam menciptakan azas kekeluargaan. Usaha koperasi adalah usaha yang sesuai dengan demokrasi ekonomi, karena didalam demokrasi ekonomi terdapat unsur-unsur usaha koperasi. 
Koperasi itu sendiri memiliki makna kusus ialah sebuah badan usaha yang memiliki anggota dan setiap anggotanya memiliki tugas dan tanggungjawab masing-masing dan berdasarkan pada perekonomian rakyat.

Laporan keuangan pada Koperasi Tani "CATUR KARYA" Desa Sari Mulya Kecamatan Sungai Loban Kabupaten Tanah Bumbu ini belumlah dapat memberikan informasi yang lebih berguna, lebih mendalam dan tajam dengan teknik tertentu. Analisis atas laporan keungan dan interprestasinya pada hakekatnya adalah untuk mengadakan penilaian atas keadaan keuangan Koperasi Tani 'CATUR KARYA" Desa Sari Mulya Kecamatan Sungai Loban Kabupaten Tanah Bumbu tersebut dan berpotensi untuk memajukan melalui laporan keuangan koperasi tersebut.

Laporan keuangan adalah bentuk pertanggungjawaban pemerintah, oleh karena itu sebagai alat pertanggungjawaban, koperasi perlu menyusun laporan keuangan yang merupakan salah satu sumber informasi yang relevan dan dapat diandalkan untuk pengambilan suatu keputusan, perencanaan maupun pengendalian suatu koperasi dalam jangka waktu yang telah di tentukan. Laporan keuangan pada koperasi ini memiliki perbedaan dengan laporan keuangan pada badan usaha atau perusahaan lainnya. Laporan Keuangan tersebut diantaranya adalah terletak pada perkiraan modal, terdiri dari Simpanan Pokok, Simpanan Wajib, Simpanan Sukarela, Sisa Pinjaman Modal Dari Bank. Pada koperasi tani "CATUR KARYA" ini Laporan Laba Rugi disebut Laporan Perhitungan Dasar Modal Koperasi dan untuk akun-akun tertentu seperti Piutang, Pendapatan, Kewajiban, dan lainnya harus dibedakan antara transaksi yang terjadi dengan anggota dan non anggota koperasi.
Laporan keuangan koperasi merupakan suatu pelaporan yang mengenai pertanggungjawaban kegiatan usaha kepada pihak luar yang mempunyai hubungan dengan koperasi baik sebagai anggota koperasi maupun sebagai kreditur.

Koperasi ini memiliki perkembangan selama 6 tahun terakhir, yaitu sebagai berikut :

Tabel 1.1Perkembangan Koperasi 6 Tahun Terakhir (2012-2017).

Sumber : Koperasi Tani Catur Karya.

Berdasarkan fenomena atau kejadian yang ditemukan dilapangan bahwa Koperasi Tani 'Catur Karya', Desa Sari Mulya Kecamatan Sungai Loban Kabupaten Tanah Bumbu ini tidak sepenuhnya menyajikan laporan keuangan secara lengkap dan menyeluruh, permasalahan yang timbul pada Koperasi Tani 'Catur Karya', Desa Sari Mulya Kecamatan Sungai Loban Kabupaten Tanah Bumbu, hal ini dilihat dari segi laporan Keuangan Koperasi yang tidak mencerminkan kinerja yang sesungguhnya hanya sebagian

\begin{tabular}{|c|c|c|c|c|c|c|c|}
\hline & Tenis Data & 2012 & 2013 & 2014 & 2015 & 2016 & 2017 \\
\hline 1. & Anggota & 153 & 175 & 209 & 243 & 275 & 317 \\
\hline 2. & $\begin{array}{l}\begin{array}{l}\text { Simpanan } \\
\text { Pokok }\end{array} \\
\end{array}$ & .200 .000 & 69.200 .000 & 83.400 .00 & 96.70 & .000 & 000 \\
\hline 3. & $\begin{array}{l}\text { Simpanan } \\
\text { Wajib }\end{array}$ & 161.212 .826 & 193.424 .000 & $\begin{array}{l}235.864 .0 \\
00\end{array}$ & 280.440 .000 & 5.528 .000 & 00.000 .000 \\
\hline 4. & $\begin{array}{l}\text { Simpanan } \\
\text { Sukarela }\end{array}$ & 41.737 .137 & 67.022 .209 & 71.818 .09 & 119.730 .672 & 145.767 .016 & 222.299 .366 \\
\hline 5 & SHU & 152.634 .135 & 153.090 .398 & $\begin{array}{l}172.08 \\
81\end{array}$ & 155.814 .782 & 156.505 .778 & 193.027.291 \\
\hline
\end{tabular}
saja yang disajikan. Jadi selama ini tidak ada laporan keuangan yang relevan. Bertolak pada pernyataan tersebut diatas, maka dengan ini penulis ingin mencoba menganalisis laporan keuangan pada koperasi tersebut dengan mengangkat judul : 'Analisis Kinerja Laporan Keuangan Pada Koperasi Tani Catur Karya Desa Sari Mulya Kecamatan Sungai Loban Kabupaten Tanah Bumbu Periode 2012 - 2017',

\section{Studi Literatur}

Laporan keuangan merupakan sumber terpenting dalam sebuah koperasi karena sebagai media informasi yang mencatat ringkasan dari transaksitransaksi keuangan selama tahun buku yang bersangkutan. Melalui laporan keuangan, para anggota koperasi dapat mengetahui kondisi kinerja pengurus 
keuangan koperasi pada periode tertentu. Jumingan (2015:4) mengatakan laporan keuangan adalah : hasil tindakan pembuatan ringkasan data keuangan organisasi Laporan keuangan ini disusun dan ditafsirkan untuk kepentingan manajemen dan pihak lain yang menaruh perhatian atau mempunyai kepentingan dengan data keuangan organisasi.Margretha (2013:20) juga mengatakn bahwa "Laporan keuangan adalah laporan yang memberikan gambaran akuntansi atas operasi serta posisi keuangan organisasi". Selanjutnya menurut Fahmi (2013:22), Laporan keuangan adalah suatu informasi yang menggambarkan kondisi suatu organisasi, dimana selanjutnya itu akan menjadi suatu informasi yang menggambarkan tentang kinerja suatu organisasi.

Berdasarkan pengertian-pengertian laporan keuangan tersebut diatas, maka yang dimaksud dengan laporan keuangan koperasi adalah hasil tindakan perbuatan ringkasan data keuangan koperasi oleh pengurus yang memberikan gambaran akuntansi atas operasi serta posisi keuangan, dimana selanjutnya akan menjadi suatu informasi yang menggambarkan kinerja koperasi ttersebut.

\section{Jenis Laporan Keuangan Koperasi}

Laporan keuangan memiliki beberapa jenis, baik laporan utama dan laporan pendukung yang merupakan hasil akhir proses akuntansi. Menurut Munawir (2014:13) dalam bukunya "Analisa Laporan Keuangan" menyebutkan : Laporan Keuangan pada umumnya terdiri dari Neraca, Laporan Laba Rugi, dan Laporan Perubahan Modal atau Labayang ditahan, walaupun dalam prakteknya sering diikutsertakan beberapa daftar yang sifatnya untuk memperoleh kejelasan lebih lanjut. Misalnya, Laporan Perubahan Modal Kerja, Laporan Arus Kas, Perhitungan Harga Pokok, maupun daftardaftar lampiran yang lain.

Jenis laporan keuangan dalam buku Akuntansi Koperasi "Laporan Keuangan koerasi terdiri dari : Perhitungan Hasil Usaha, Neraca, Laporan Arus Kas dan Laporan Promosi Ekonomi Anggota”.

Berdasarkan penjelasan diatas, dapat disimpulkan bahwa jenis-jenis laporan keuangan koperasi terdiri dari :
a. Neraca.
b. Perhitungan Hasil Usaha
c. Laporan Arus Kas
d. Laporan Promosi Ekonomi Anggota

\section{Metode Penelitian}

Penelitian ini mengenai analisis kinerja laporan keuangan pada Koperasi Tani Catur Karya penelitian ini merupakan penelitian deskriptif dengan pendekatan kuantitatif, dimana penelitian deskriptif adalah penelitian yang dirancang untuk menggambarkan subjek penelitian dengan cara yang akurat. Lebih sederhananya, penelitian deskriptif adalah semua tentang deskripsi subjek yang diteliti dalam studi tersebut, sedangkan kuantitatif adalah penelitian ilmiah yang sistematis terhadap bagian-bagian dan fenomena serta hubungan-hubungannya.

Populasi dalam penelitian ini adalah Laporan Keuangan Audit Tahun 2012 sampai dengan 2017 Pada Koperasi Tani Catur Karya. Sedangkan sampel dalam penelitian yang dilakukan ini adalah Kinerja Laporan Keuangan Pada Koperasi Tani Catur Karya dengan menggunakan 6 aspek yaitu aspek permodalan, aspek kualitas produktif, aspek efisiensi, aspek likuiditas, aspek kemandirian dan pertumbuhan, dan aspek jati diri koperasi. 


\section{Hasil Penelitian Dan Pembahasan}

Dari hasil penelitian yang telah dilakukan terhadap Koperasi Tani Catur Karya Desa Sari Mulya Kecamatan Sungai Loban Kabupaten Tanah Bumbu Analisis laporan keuangan melalui enam aspek diantaranya adalah :

1. Aspek Permodalan menunjukan jumlah modal sendiri mengalami penurunantingkat prosentase dari tahun sebelumnya, sehingga untuk kedepannya tingkat prosentase modal dapat ditingkatkan, agar kedepannya permodalan koperasi mampu mencukupi untuk pengeluaran koperasi.

2. Aspek Kualitas Aktiva Produktif menunjukan volume pinjaman kepada pinjaman berisiko mendapatkan hasil seimbang karena pinjaman hanya diperuntukkan kepada anggota koperasi serta pinjaman bermasalah mengalami penurunan tingkat porsentasenya, sehingga koperasi untuk kedepannya mampu mengurangi tingkat risiko pinjaman yang diberikan, agar pinjaman koperasi kedepannya mampu meningkat dengan risiko rendah.

3. Aspek Efisiensi menunjukan tingkat pelayanan koperasi terhadap beban operasional koperasi atau terhadap anggotanya di setiap tahunnya, hal ini menunjukan pelayanan koperasi kepada anggota sudah baik, tetapi untuk kedepannya koperasi mampu lebih sebagai pelayanan bagi anggota, agar pelayanan kepada anggota atau masyarakat kedepannya mampu lebih baik.

4. Aspek Likuiditas ini dinilai dengan rasio kas dan bank terhadap kewajiban, dalam penelitian ini kas dan bank mampu menutupi kewajiban yang ditanggung koperasi, sehingga kewajiban koperasi mampu terbayarkan di setiap tahunnya, sehingga untuk kedepannya koperasi mampu meningkatkan kas dan bank serta mampu mengurangi kewajiban di tahun berikutnya.

5. Aspek Kemandirian dan Pertumbuhan koperasi yang dinilai ialah rentabilitas aset dan rentabilitas modal sendiri dalam hal ini nilai hasil usaha lebih tinggi terhadap aset dan modal sendiri, untuk kedepannya koperasi mampu bertahan atau meningkatkan lebih kepada sisa hasil usahanya agar sisa hasil usaha mampu seimbang dengan asset yang dimiliki koperasi.

6. Aspek Jati Diri Koperasi dinilai rasio partisipasi bruto dimana dimaksudkan untuk mengukur kemampuan koperasi dalam mengaktifkan anggotanya, dalam hal ini koperasi mampu meningkatkan simpan pinjam dari tahun sebelumnya, sehingga untuk kedepannya koperasi lebih meningkatkan dalam hal simpan pinjam.

Dari aspek tersebut diatas kedepannya hendaknya koperasi mampu meningkatkan kinerja laporan keuangan serta melakukan analisis secara terus menerus agar selain dapat mengetahui pertumbuhan koperasi juga dapat menilai kinerja atas operasi koperasi melalui laporan keuangan, sehingga dapat menunjang dan meningkatkan kesejahteraan yang lebih baik untuk pengurus dan anggota koperasi.

\section{Kesimpulan}

Berdasarkan hasil analisis kinerja keuangan yang telah dilakukan maka 
dapat di tarik kesimpulan bahwa Kinerja Keuangan Koperasi Tani Catur Karya Desa Sari Mulya Kecamatan Sungai Loban Kabupaten Tanah Bumbu dengan menggunakan 6 aspek maka diperoleh kesimpulan sebagai berikut :

Analisis Kinerja Laporan Keuangan Pada Koperasi Tani Catur Karya Desa Sari Mulya Kecamatan Sungai Loban Kabupaten Tanah Bumbu Periode 20122017 dengan menggunakan 6 aspek menunjukan kesimpulan :

a. Aspek permodalan menunjukan skor sebesar 7,8 pada tahun 2012-2013, tahun 2014 sebesar 6,3, tahun 20152016 sebesar 7,8, dan pada tahun 2017 sebesar 8,55. Artinya terjadi peningkatan skor permodalan dari tahun sebelumnya.

b. Aspek kualitas aktiva produktif menunjukan skor sebesar 20 pada tahun 2012-2013 dan pada tahun 2014-2017 menunjukan skor sebesar 18. Artinya terjadi penurunan skor dalam aspek kualitas produktif dari tahun sebelumnya.

c. Aspek efisiensi menunjukan skor sebesar 4,5 pada tahun 2012 sampai dengan 2017. Artinya pada aspek efisiensi ini tidak terjadi perubahan skor dari tahun-tahun sebelumnya.

d. Aspek likuiditas menunjukan skor sebesar 2,50 pada tahun 2012 sampai dengan 2017. Artinya pada aspek likuiditas ini tidak terjadi penurunan skor dari tahun sebelumnya.

e. Aspek kemandirian dan pertumbuhan menunjukan skor sebesar 6 pada tahun 2012 sampai dengan 2017. Artinya pada aspek kemandirian dan pertumbuhan tidak terjadi penurunan skor dari tahun sebelumnya.

f. Aspek jati diri koperasi menunjukan skor sebesar 1,75 pada tahun 2012 sampai dengan 2017. Artiya pada aspek jati diri koperasi tidak terjadi penurunan skor pada tahun sebelumnya.
Berdasarka hasil penelitian, pembahasan dan kesimpulan yang diperoleh, maka Koperasi Tani Catur Karya berdasarkan aspek permodalan dengan menigkatkan tingkat permodalan untuk pembiayaan koperasi, aspek kualitas aktiva produktif dengan cara meningkatkan pinjaman dengan tingkat risiko kecil, aspek efisiensi dengan meningkatkan pelayanan kepada para anggota serta masyarakat sekitar, aspek likuiditas dengan meningkatkan saldo kas dan bank serta meminimalisir tingkat kewajiban koperasi, aspek kemandirian dan pertumbuhan, serta aspek jati diri dengan cara meningkatkan tingkat simpan pinjam koperasi kepada para anggotanya, hal tersebut bahwa koperasi menunjukan dalam kategori tidak sehat, sehingga koperasi untuk kedepannya mampu meningkatkan dari enam aspek tersebut sehingga koperasi berada dalam predikat atau kategori sehat dan mampu lebih baik lagi terhadap pelayanan bagi masyarakat serta anggotanya.Paparan Pada bagian kesimpulan dituliskan temuan penelitian secara singkat, ringkas dan padat, tanpa tambahan intepretasi baru lagi. Pada bagian ini juga dapat dituliskan kebaruan penelitian, kelebihan dan kekurangan dari penelitian, serta rekomendasi untuk penelitian selanjutnya.

\section{DAFTAR PUSTAKA}

Adisaputro dan Asri, 2013, Keperilakuan, BPFE, Yogyakarta.

Baswir, 2015, Koperasi Indonesia, Fakultas Ekonomi dan Bisnis

Universitas Gajah Mada, Yogyakarta

Fahmi, 2013, Analisis Laporan Keuangan, Alfabeta Ghozali Imam, Bandung.

Gitosudarmo dan Najmudin, 2013, Teknik Proyeksi Bisnis Edisi Pertama, BPFE, Yogyakarta.

Hidayah, Nur, 2016, Analisis Kinerja Keuangan Pada Koperasi Serba Usaha Bina Usaha Di Kabupaten Gowa, Skripsi, Fkultas Ekonomi Negeri Makassar, Makassar. 
Jumingan, 2015, Jurnal Bisnis Dan Manajemen Journal of Business And Management, MM UNS, Surakarta Jawa Tengah.

Margaretha, 2013, Universal Journal of Management and Social Sciences, Widya Mandala University, Surabaya.

Moh. Hatta, Baswir, 2015, Koperasi Indonesia, Fakultas Ekonomi dan

Bisnis Universitas Gajah Mada, Yogyakarta

Munawir, 2014, Analisa Laporan Keuangan, Liberty, Yogyakarta.

Peraturan Menteri Negara Koperasi dan UKM No. 06 Tahun 2016, Jakarta

PSAK, 2007, Standar Akuntansi Keuangan, Jakarta

Ratau, Ketut, 2016, Analisis Kinerja Keuangan Koperasi Simpan Pinjam Swadaya di Desa Banyuwangi Kecamatan Buleleng Kabupaten Buleleng, Skripsi, Fakultas Ekonomi Universitas Tabanab, Tabanan.
Rudianto, 2015, Pengantar Akuntansi Konsep \& Teknik Penyusunan Laporan Keuangan, Erlangga, Jakarta.

Samperuru, Eston Septanugrah, 2015, Analisis Rasio Keuangan Sebagai Alat Untuk Mengukur Kinerja Keuangan pada Koperasi Simpan Pinjam (KSP) Balo' Toraja Kabupaten Tana Toraja Periode 2005-2014, Skripsi, Fakultas Ekonomi Dan Bisnis Universitas Hasanudin, Makassar.

Subandi, 2014, Perkoperasian dan Pedoman Umum Akuntansi Koperasi,

PT. Tatanusa, Jakarta.

Sugiyono, 2015, Pengertian Populasi dan Sampel,

http:adeletorn.blogspot.com/2015/04/pen gertian-populasi-dan-sampel-

menurut.html. (Di Akses tanggal 10 Agustus 2018). 